\title{
Feeding corn and barley based concentrates to grazing dairy cows. I. Responses to insulin and $\beta$-adrenergic stimuli
}

\author{
GA Gagliostro 1, SE Lavandera 2, SC García 1, FJ Santini 1 \\ 'INTA EEA Balcarce, CC 276-7620 Balcarce,2 Consejo Nacional de Investigaciones \\ Cientificas y Técnicas (CONICET), Argentine
}

A high protein (CP) non structural carbohydrate (NSCH) ratio in autumn-winter forages lead to high rumen ammonia $\left(\mathrm{N}-\mathrm{NH}_{3}\right)$ levels (16$60 \mathrm{mg} / \mathrm{dl}$ ). Feeding concentrates with different ruminal starch degradability may be a way to synchronize protein/energy availabilities reducing the risk of $\mathrm{N}-\mathrm{NH}_{3}$ excess. Hyperammonemia may induce insulin resistance and enhanced $B$-adrenergic responses (Fernández et al, 1988, J Anim Sci, 66, 3259-3266 ; Visek, 1984, J Dairy Sci, 67, 481-498; Symonds et al, 1981, Br J Nutr, 46,481-486).

Twenty seven Holstein cows $(85 \pm 17$ days postpartum) grazing an oat sward $(C P=23.9$ $\%, \mathrm{NSCH}=16.9 \%$ ) and a pasture of ryegrass $(\mathrm{CP}=15.9 \%, \mathrm{NSCH}=19.5 \%)$ in winter were assigned to three treatments : PA : only forage, $\mathrm{CO}$ : forage plus $7 \mathrm{~kg} / \mathrm{cow} / \mathrm{d}$ of a corn $(75 \%)$ based concentrate and BA : forage plus 7 $\mathrm{kg} / \mathrm{cow} / \mathrm{d}$ of a barley ( $85 \%$ ) based concentrate. Preprandial jugular blood samples were taken (5 wks) to evaluate metabolite concentrations. Samples were taken before (INS-0), 30 (INS30), 60 (INS-60) and 90 (INS-90) minutes after an intravenous bovine insulin challenge $(0.12$ units/kg body weight) (wk 2) and before (ISO-0) and 15 minutes after (ISO-15) isoproterenol challenge ( $4 \mathrm{nmol} / \mathrm{kg}$ body weight) (wk 3). Urea, triglycerides (TG), glucose and free fatty acids (FFA) were determined using enzymatic kits. Data were analysed using an split-plot design with treatment as main plot and week or sampling time as secondary plot.
Intake of concentrates was 6.3 and 5.3 $\mathrm{kg} / \mathrm{cow} / \mathrm{d}$ in $\mathrm{CO}$ and BA. Forage dry matter intake was higher in $P A$ respect to $C O$ and $B A$ (11.93 vs 11.02 and $10.75 \mathrm{~kg} D M /$ cow $/ \mathrm{d}$, $\mathrm{P}<0.05)$. Milk yield was higher in $\mathrm{CO}(21.5$ $\mathrm{kg} / \mathrm{cow} / \mathrm{d})$ respect to $P A(17.0)(P<0.05)$ but similar between BA $(18.4 \mathrm{~kg} / \mathrm{cow} / \mathrm{d})$ and the other treatments. Milk fat was lower in BA (2.84 $\%$ ) respect to MA $(3.01 \%)$ and PA $(3.45 \%)$. Rumen N-NH3 (six additional fistulated cows) was $15.7,14.1$ and $15.7 \mathrm{mg} / \mathrm{dl}$ in PA, CO and $\mathrm{BA}(\mathrm{P}<0.15)$ (range 5 to $26 \mathrm{mg} / \mathrm{dl}$ ). Plasma urea was higher in $\mathrm{PA}(24.2 \mathrm{mg} \%)$ respect to $\mathrm{BA}$ $(21.2 \mathrm{mg} \%)(P<0.05)$ and similar between $\mathrm{CO}$ $(22.3 \mathrm{mg} \%)$ and the other treatments. Plasma urea correlated with milk yield $(-0.204, P<0.05)$ and FFA $(0.28, P<0.01)$. Glucose, $T G$ and $F F A$ were similar across treatments. Glucose and FFA concentrations for ISO-0 were 74.7, 71.8 and $70.0 \mathrm{mg} / \mathrm{dl}$ and 558,412 and $364 \mu \mathrm{eq} / \mathrm{l}$ in $\mathrm{PA}, \mathrm{CO}$ and $\mathrm{BA}$ respectively ( $\mathrm{P}>0.05)$. ISO-15 values were $84.3,81.3,80.0 \mathrm{mg} / \mathrm{dl}$ for glucose and $906,722,770 \mu e q / /$ for FFA in PA, CO and $B A$ respectively $(P>0.05)$. Changes in plasma glucose and FFA concentrations after INS challenge did not differ.

Higher $\beta$-adrenergic responses or resistance to insulin action were not observed in cows grazing pastures rich in $\mathrm{CP}$ in winter but in the experiment, the forage $\mathrm{NSCH}$ content was high and $\mathrm{N}-\mathrm{NH} 3$ and plasma urea were relatively low.

\begin{tabular}{lcccc} 
& PA & CO & BA & Mean \\
\hline $\begin{array}{l}\text { Glucose }(m g / d) \\
\text { INS-0 }\end{array}$ & 78.2 & 75.6 & & \\
INS-30 & 40.1 & 34.0 & 77.1 & $76.9^{\mathrm{a}}$ \\
INS-60 & 50.1 & 48.7 & 40.27 & $38.1^{\mathrm{b}}$ \\
INS-90 & 65.1 & 60.5 & 51.5 & $50.1^{\mathrm{c}}$ \\
FFA $(\mu$ eq/I) & & 64.4 & $63.3^{\mathrm{d}}$ \\
INS-0 & 338 & 309 & 401 & $349^{\mathrm{a}}$ \\
INS-30 & 271 & 246 & 271 & $262^{\mathrm{b}}$ \\
INS-60 & 381 & 328 & 334 & $348^{\mathrm{a}}$ \\
INS-90 & 490 & 359 & 393 & $414^{\mathrm{c}}$ \\
\hline
\end{tabular}

a,b,c,d : means with different letters differ $(P<0.05)$. Neither treatment nor interaction effects were detected 